\title{
Evidence for Glycine Modulation of Excitatory Synaptic Inputs to Retinal Ganglion Cells
}

\author{
Peter D. Lukasiewicz ${ }^{1,2}$ and Renee C. Roeder ${ }^{1}$ \\ 'Department of Ophthalmology and Visual Sciences and 'Department of Anatomy and Neurobiology, Washington \\ University School of Medicine, St. Louis, Missouri 63110-1093
}

The actions of glycine on the NMDA receptor-mediated synaptic responses of ganglion cells were studied in the tiger salamander retinal slice. Ganglion cell excitatory postsynaptic currents (EPSCs) were elicited either by exciting bipolar cells with potassium puffs or by light stimulation, and were measured using whole-cell patch-clamp techniques. Increasing bath glycine concentrations to 10 $\mu \mathrm{M}$ had little effect on the amplitude of the puff-evoked EPSCs, indicating either that synaptic glycine concentrations were saturating or that the added glycine was buffered by uptake mechanisms. However, 5,7-dichlorokynurenic acid (5,7-DCK), an antagonist for the glycine site on the NMDA receptor, reduced the ganglion cell responses to NMDA puffs, and reduced the potassium puff- and lightelicited EPSCs. The $\mathrm{IC}_{50}$ values for 5,7-DCK became larger with increasing glycine concentrations, but not with increasing NMDA concentrations, indicating that 5,7-DCK acted at the glycine site. The $I_{50}$ values for 5,7-DCK were increased with stronger potassium puffs or light stimuli, suggesting that synaptic glycine levels increased with the strength of the stimuli. EPSCs measured in ON-OFF ganglion cells at light $O N$ and OFF were reduced by 5,7-DCK. For dim light stimuli, the IC $_{50}$ values were lower for the OFF EPSCs compared to the ON EPSCs, indicating that glycine concentrations were different at the times of OFF and ON activity. Estimates of synaptic glycine concentrations suggest that for dim light stimuli, concentrations at the OFF synapses were not saturated, but concentrations at the $O N$ synapses were saturated.

[Key words: glycine, NMDA, glutamate, retinal ganglion cell, 5,7-dichlorokynurenic acid, tiger salamander]

Light-elicited, excitatory synaptic inputs to salamander retinal ganglion cells are mediated by both NMDA and non-NMDA receptors (Lukasiewič and McReynolds, 1985; Mittman et al., 1990; Diamond and Copenhagen, 1993). The NMDA-mediated component of the ganglion cell light response, like other NMDA responses, is voltage and magnesium dependent (Mayer et al., 1984; Nowak et al., 1984; Mittman et al., 1990). NMDA recep-

Received July 21, 1994; revised Jan. 18, 1994; accepted Jan 20, 1994

We thank Jean Lawrence, John McReynolds, and Carmelo Romano for their helpful comments on the manuscript. This work was supported by NIH Grants EY08922 (P.D.L.) and EY02687. a Core Grant to the Department of Ophthalmology, and a Research to Prevent Blindness Miriam and Benedict Wolf Scholars Award (P.D.L.).

Correspondence should be addressed to Dr. Peter D. Lukasiewicz at the above address.

Copyright $\circlearrowleft 1995$ Society for Neuroscience $0270-6474 / 95 / 154592-10 \$ 05.00 / 0$ tors can be modulated by several substances, many of which are found in the retina. Among others, there are binding sites on the NMD $\Lambda$ receptor complex for glycine (Johnson and Ascher, 1987; Mayer et al., 1989), $\mathrm{Mg}^{2+}$ (Mayer et al., 1984; Nowak et al., 1984), $\mathrm{Zn}^{2+}$ (Westbrook and Mayer, 1987; Peters et al., 1987) and polyamines (Ransom and Strec, 1988; Williams et al., 1990).

Glycine was shown to modulate the function of NMDA receptors by Johnson and Ascher (1987). They demonstrated that glycine enhanced the actions of glutamate at NMDA receptors. Subsequent work showed that glycine acted as a coagonist at many NMDA receptor subtypes (Kleckner and Dingledine, 1988). For these receptors, both glutamate and glycine must bind to the NMDA receptor for the channel to open. Glycine acts at a strychnine-insensitive binding site (the glycine modulatory site) where its actions can be blocked by relatively selective competitive antagonists (Kemp et al., 1988; Huettner, 1989; McNamara et al., 1990). In addition to its role as a coagonist, glycine has been shown to decrease desensitization of NMDA receptors (Mayer et al., 1989; I ester et al., 1993). Glycine has been shown to enhance NMDA responses on isolated retinal ganglion cells (Yazejian and Fain, 1992), and antagonists for the glycine modulatory site have been shown to reduce ganglion cell NMDA responses (Gottesman and Miller, 1992; Yazejian and Fain, 1992).

Glycine's role as a modulator of NMDA receptor-mediated synaptic inputs in the retina has gone largely unstudied. Salamander ganglion cells receive glycinergic synaptic inputs from several major subtypes of amacrine cells (Yang et al., 1991), including transient, ON-OFF amacrine cells (Belgum et al., 1984; Yang et al., 1991). At least one-third of the amacrine cells in salamander retina utilize glycine as a transmitter (Yang and Yazulla, 1988). In addition to their direct inhibitory roles (Miller et al., 1981; Belgum et al., 1984; Lukasiewicz and Werblin, 1990), glycinergic synaptic inputs may also regulate both the magnitude and the kinetics of ganglion cell excitatory synaptic inputs.

We report here that EPSCs elicited in ganglion cells either by light or by puffs of potassium in the outer retina were reduced by 5,7-dichlorokynurenic acid (5,7-DCK), a competitive antagonist at the glycine modulatory site. The $\mathrm{IC}_{51}$ for $5,7 \mathrm{DCK}$ changed as a function of light or puff stimulus strength. This suggests that glycine concentrations at the NMDA receptors are not constant. These findings suggest that glycinergic amacrine cells may modulate the strength of excitatory synaptic inputs to ganglion cells.

\section{Materials and Methods}

Whole-cell patch recording in retinal slices. Whole-cell patch recordings (Hamill et al., 1981) were made from ganglion cells in retinal slice 
preparations (Werblin, 1978). The recording procedures have been described in detail elsewhere (Barnes and Werblin, 1986, 1987; Lukasiewicz and Werblin, 1988; Lukasiewicz and Werblin, 1994). Slices were prepared by placing a small square, cut from the back of the eye, vitreal side down onto a piece of Millipore filter. The sclera was pulled away, leaving the retina adhering to the filter. The retina and filter were then sliced will a lissue chopper at $150 \mu \mathrm{m}$ intervals using a micrometercontrolled stage. The slices were positioned so that the cells along the cut face of the slice could be viewed by the experimenter. The slices were immobilized by embedding the ends of the filter, which extended beyond the retina, in vacuum grease.

Electrode and bathing solutions. The intracellular/electrode solution (Mittman et al., 1990) consisted of (in $\mathrm{mM}$ ) cesium fluoride 90.5, sodium chloride 3.4 , magnesium chloride 0.4 , calcium chloride 0.4 , EGTA 11 , and sodium HEPES 10, adjusted to $\mathrm{pH} 7.7$ with cesium hydroxide (the free calcium concentration was $10^{-9} \mathrm{M}$ ). Fluoride greatly enhanced the probability of obtaining high quality seals and had no effect on ganglion cell EPSCs ( Mittman et al., 1990; Diamond and Copenhagen, 1993; Lukasiewicz and Werblin, 1994). The bathing medium contained (in $\mathrm{mM}$ ) sodium chloride 112 , potassium chloride 2 , calcium chloride 2, magnesium chloride 1, glucose 5, and HEPES 5, adjusted to $\mathrm{pH} 7.8$ with $\mathrm{NaOH}$. Unless otherwise indicated, all chemicals were obtained from Sigma Chemical (St. Louis, MO). CNQX (6-cyano-7-nitroquinoxaline-2,3-dione) and the glycine site antagonists, 7-chlorokynurenic acid and 5,7-dichlorokynurenic acid, were obtained from Research Biochemicals International (Natick, MA). Experiments were performed at room temperature $\left(20-24^{\circ} \mathrm{C}\right)$.

Drugs were applied locally over a relatively large area of the slice under study (several $\mathrm{mm}$ in width) by a gravity-driven superfusion system at a rate of $1-2 \mathrm{ml} / \mathrm{min}$. Fine PE tubings from ten $10 \mathrm{ml}$ syringes were fastened inside a plastic micropipette tip. The pipette tip $(400 \mu \mathrm{m}$ inner diameter) was placed at least I mm from the slice. Solutions flowed from the ganglion cell side to the photoreceptor side of the slice. In addition to the local drug application, the entire recording chamber was continually superfused at a rate of $1-2 \mathrm{ml} / \mathrm{min}$ to accelerate washout of the applied drugs.

Puffing potassium at the bipolar dendrites. Synaptic responses in ganglion and amacrine cells were elicited by "puffing" potassium chloride $(\mathrm{KCl})(120 \mathrm{~mm})$ through pipettes with $1 \mu \mathrm{M}$ diameter tips onto bipolar cell dendrites (Lukasiewicz and Werblin, 1994). The resulting depolarization of bipolar cells caused them to release glutamate onto ganglion cells. Puffs of potassium were given once every $40 \mathrm{sec}$ to avoid desensitizing the excitatory synaptic inputs. The $\mathrm{K}^{+}$puffing solution was similar to the bathing solution, but equimolar potassium chloride was substituted for sodium chloride. A Picospritzer (General Valve Corp., Fairfield, $\mathrm{NJ}$ ) was used to puff $\mathrm{K}^{+}$onto the dendrites (pressure, 5-20 psi). The puffer pipette tip was positioned less than $10 \mu \mathrm{m}$ from the bipolar cell dendrites. The puff method and its calibration are described in detail in Lukasiewicz and Werblin (1990).

The ganglion cell EPSCs were pharmacologically isolated by blocking GABAergic and glycinergic inhibitory synaptic inputs with picrotoxin $(150 \mu \mathrm{M})$ and strychnine $(2 \mu \mathrm{M})$, respectively (Belgum et al., 1984; Lukasiewicz and Werblin, 1990; Mittman et al., 1990; Diamond and Copenhagen, 1993). Voltage-gated sodium currents were blocked by including $0.5 \mu \mathrm{M}$ tetrodotoxin in the bath, and voltage-gated potassium currents were blocked by including cesium in the recording electrodes (Lukasiewicz and Werblin, 1988).

Light stimulation. The light source was a tungsten halogen lamp (20 W) (Ealing Electro-Optics, Holliston, MA). The light was focused onto the preparation through the microscope objective via a light pipe that was attached to the horizontal eyepiece tube of a Nikon Q2 quadrocular body. Full-field, white light stimuli were used. A shutter, controlled by a $33 \mathrm{MHz}$ 386- $\mathrm{PC}$, was placed in the light path and controlled the duration of the light stimuli. Neutral density filters were used to attenuate the intensity of the light stimulus. The intensity of the unattenuated light stimulus was equivalent to $3.6 \times 10^{8}$ photons per $\mu \mathrm{m}^{2}$ per sec of a monochromatic light of $500 \mathrm{~nm}$.

For light stimulation experiments, the dissections and preparation of the slices were performed under dim red illumination. Infrared viewers (Electrophysics Corp., Nutley, NJ) were used to view the slices under infrared illumination during the recording procedures. Since dim red illumination was used during the dissection, the slices may have been incompletely dark adapted (see Hensley et al., 1993)

Liquid junction potential correction. Membrane potential values given in this article were corrected for junction potentials. Liquid junction potentials were determined as described by Fenwick et al. (1982). They were typically $-6 \mathrm{mV}$ for the cesium fluoride $(\mathrm{CsF})$ electrode solution.

Cell identification. Ganglion cells were identified by their characteristic current responses to light stimuli (Mittman et al., 1990). More than $90 \%$ of ganglion cells were ON-OFF cells that responded with transient EPSCs at light onset and offset. The remaining cells were $O N$ cells that responded with a sustained EPSC to the light stimulus. Almost all of the results reported here were obtained from ON-OFF ganglion cells. Some cells were stained by including Lucifer Yellow $\mathrm{CH}(0.25 \%)$ ( $\mathrm{Al}-$ drich Chemicals, Milwaukee, WI) in the electrode (Stewart, 1978). The stain diffused into the cell and its processes so that identification could be made following the recording. Cell processes usually filled in several minutes. Cells and processes were viewed using a Nikon mercury fluorescent epiilluminator with an Omega Optical XF15 filter set (Brattleboro, VT). Ganglion cell subtypes were identified by the ramification of their dendrites at different depths in the inner plexiform layer (IPL) (Famiglietti and Kolb, 1976; Famiglietti et al., 1977; Nelson et al., 1978).

Recording system. Cells were viewed with a Nikon Optiphot 2 microscope modified to have a fixed stage. A Nikon $40 \times$ long-working distance water immersion objective with Hoffman Modulation contrast optics (Modulation Optics, Inc., Greenvale, NY) allowed for easy visualization of cells on the surface of the slice. Recordings were obtained primarily with a Dagan $3900 \mathrm{~A}$ (Minneapolis. MN) patch clamp amplifier, although some recordings were obtained with an Axopatch $200 \mathrm{~A}$ (Axon Instruments, Foster City, CA). Electrodes were pulled from borosilicate glass (TW 150F-4, World Precision Instruments, Sarasota, FL) with a Sachs-Flaming puller (Sutter Instruments, Novato, CA) and had nedsured resistances of less than $5 \mathrm{M} \Omega$ The measured series resistances were typically 15-25 M $\Omega$ The magnitude of the series resistance compensation, read off of the Dagan 3900A compensation counting dial, was 5-10 M $\Omega$. pCLAMP software (Axon Instruments. Foster City, CA) was used to generate voltage command outputs, acquire data, and trigger the $\mathrm{KCl}$ application puffer. The data were digitized and stored with a $33 \mathrm{MHz}$ 386-PC using a Labmaster DMA data acquisition board (Scientific Solutions, Solon, $\mathrm{OH}$ ). Responses were filtered at $2 \mathrm{kHz}$ with the four pole Bessel low-pass filter on the Dagan 3900A and sampled at $100 \mathrm{~Hz}$. Data were analyzed using CLAMPAN (Axon Instruments, Foster City, CA). Nonlinear regression (Sigma Plot for Windows 1.02, Marquart-Levenberg algorithm; Jandel Scientific, San Rafael, CA) was used to fit the concentration-response data with Equation 1. Results are expressed as mean value \pm the sample standard deviation.

\section{Results}

Glycine site antagonists reduce ganglion cell EPSCs

In order to study the interactions between glycine and glutamate at ganglion cell NMDA receptors, we utilized selective, competitive antagonists for the glycine modulatory site. Initial experiments showed that both 5-chloroindole-2-carboxylic acid $(500 \mu \mathrm{M})$ (Huettner, 1989) or 7-chlorokynurenic acid $(5 \mu \mathrm{M})$ (Kemp et al., 1988) reversibly reduced the NMDA component of ganglion cell EPSCs. Since 7-chlorokynurenic acid can act at non-NMDA receptors (Kleckner and Dingledine, 1989), we used the more potent and selective glycine site antagonist 5,7-dichlorokynurenic acid (5,7-DCK) (McNamara et al., 1990) for all of the experiments reported here.

Figure $1 A$ shows a family of potassium puff-elicited EPSCs recorded from an $\mathrm{ON}-\mathrm{OFF}$ ganglion cell. The cell was clamped to $-30 \mathrm{mV}$ to maximize the NMDA component of the response by relieving the voltage-dependent $\mathrm{Mg}^{2+}$ blockade of the NMDA channel (Mittman et al., 1990; Diamond and Copenhagen, 1993). The bathing medium was nominally glycine free. The peak amplitude of the synaptic response was reduced by 5,7DCK in a concentration-dependent manner. The smallest effective concentration of 5,7-DCK was generally 0.1 or $0.3 \mu \mathrm{M}$. The peak amplitudes of the responses were plotted as a function of 5,7 -DCK concentration in Figure $1 B$. The solid line is the best fit obtained from the four parameter logistic function 
A

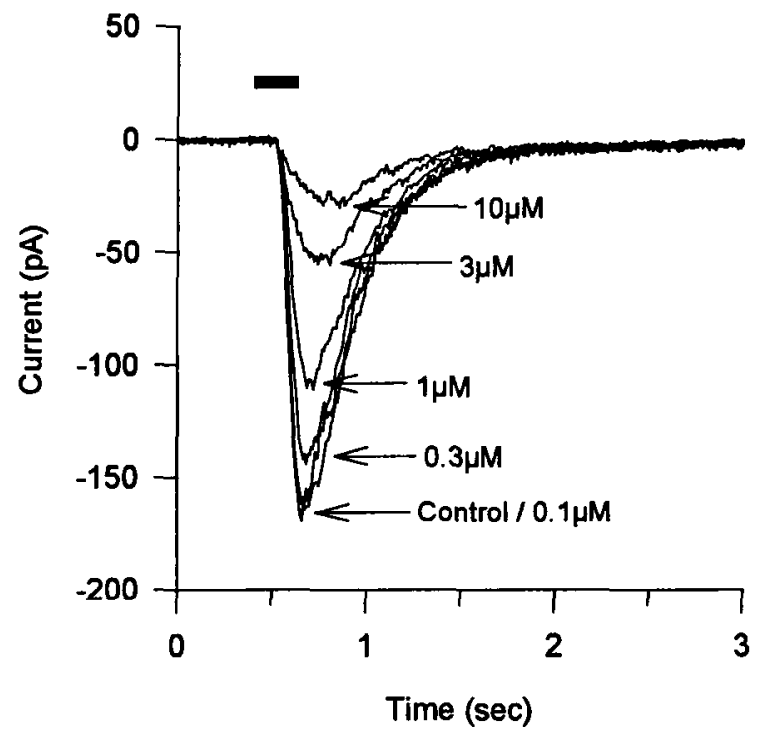

B

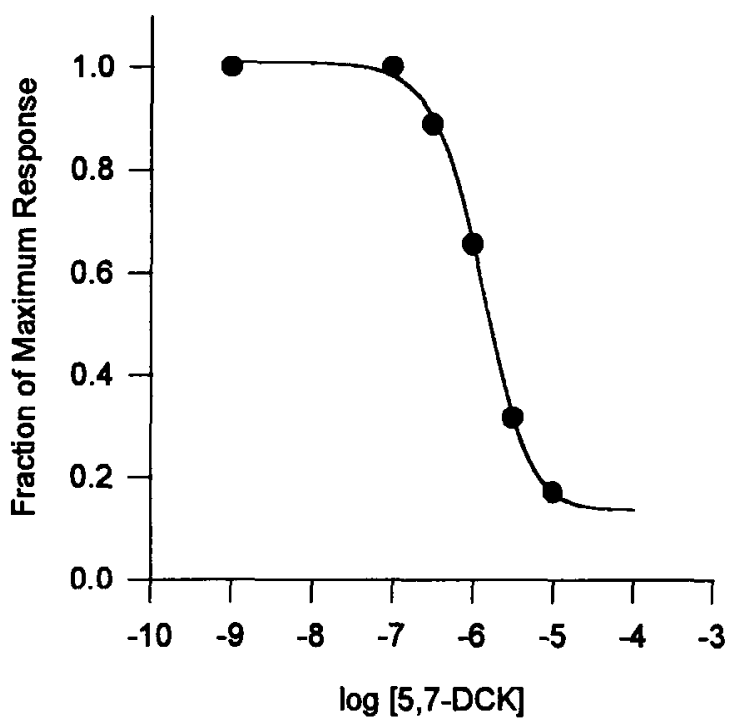

Figure 1. 5,7-Dichlorokynurcnic acid (5,7-DCK) reduces ganglion cell EPSCs. A, Family of EPSCs elicited by puffing potassium onto bipolar cell dendrites. Each current trace is the average of three to four responses recorded when the bath contained the indicated concentration of 5,7DCK. The cell was voltage clamped to $-30 \mathrm{mV}$. The duration of the puff stimulus is indicated by the bar above the current responses in this and subsequent figures. 5,7-DCK reduced the amplitude of the EPSCs in a concentration-dependent manner. $B$, Plot of the peak amplitude of the ganglion cell EPSCs as a function of log concentration of 5,7-DCK. The responses are normalized to the peak amplitude of the control response in this and subsequent figures. The peak responses recorded in the presence of different concentrations of 5,7-DCK are indicated by the solid circles. The line is the best fit obtained using Equation 1 . In this and subsequent figures, the response minimum is not zero because of the remaining non-NMDA receptor component of the response. Since CNQX also acts as an antagonist at the glycine modulatory site, it could not be used to block the nonNMDA component.

$$
\frac{I}{I_{\max }}=\frac{a-c}{1+\left(\frac{[\text { antagonist }]}{\mathrm{IC}_{50}}\right)^{\prime \prime}}+c,
$$

where $a$ is the asymptotic maximum, $b$ is the slope parameter, $c$ is the asymptotic minimum, and $\mathrm{IC}_{50}$ is the antagonist concentration that reduced $I$ to one-half of $I_{\max }$. For this cell, the $\mathrm{IC}_{50}$ for 5,7-DCK was $1.15 \mu \mathrm{M}$. The mean $\mathrm{IC}_{50}$ for the 5,7-DCKinduced reduction of the NMDA receptor-mediated EPSCs was $1.1 \pm 0.9 \mu \mathrm{M}(n=13)$ (range, $0.25-3.5 \mu \mathrm{M})$. We show below that the large variability in $\mathrm{IC}_{50}$ values can be attributed to differences in the strengths of the puff stimuli used to elicit EPSCs.

The response that remained in the presence of $10 \mu \mathrm{M} 5,7$ DCK was most likely mediated by non-NMDA receptors. This is because in the presence of $5 \mu \mathrm{M}$ CNQX, the EPSCs were completely blocked by $10 \mu \mathrm{M} 5,7-\mathrm{DCK}$ (data not shown). The time course of non-NMDA receptor component of the puff-elicited ganglion cell response was similar to that of the NMDA receptor component. Diamond and Copenhagen (1993) reported similar results for ganglion cell light-evoked EPSCs in the dark adapted retina. They suggested that the similar time courses for the two receptor components were due to the slow rate of transmitter release from bipolar cells that "smears out" the kinetic differences between NMDA and non-NMDA receptors. The similar time courses for the two glutamate receptor-mediated components of the responses in our experiments suggest that the puff stimuli also produced a slow rate of transmitter release from bipolar cells.

\section{EPSC desensitization is unaffected by glycine}

Glycine has been shown to reduce the degree of desensitization of NMDA receptors in cultured mouse hippocampal neurons
(Mayer et al., 1989). This suggests that the level of cxtracellular glycine could modulate the rate of desensitization of NMDA receptor-mediated synaptic responses. However, recent work by Lester et al. (1993) has shown that the desensitization of NMDA receptor-mediated synaptic responses in hippocampal neurons was insensitive to glycine concentration. We tested whether glycine could regulate desensitization of the NMDA receptor-mediated EPSCs in ganglion cells in the slice preparation. Figure 2 shows NMDA receptor-mediated EPSCs that were evoked with outer plexiform layer (OPL) potassium puffs, in an ONOFF ganglion cell that was voltage clamped at $-75 \mathrm{mV}$. To isolate the NMDA component of the response, the bath was nominally $\mathrm{Mg}^{2+}$ free, contained $5 \mu \mathrm{M}$ CNQX to block nonNMDA receptor-mediated synaptic inputs, and $5 \mu \mathrm{M}$ glycine to counter the competitive, antagonistic actions of CNQX at the glycine modulatory site (Lester et al., 1989). The amplitude of the EPSC was reduced to approximately $40 \%$ of its control amplitude by $2 \mu \mathrm{M} 5,7$-DCK (Fig. $2 A$ ). Figure $2 B$ shows that when the EPSC measured in the presence of $5,7-\mathrm{DCK}$ was scaled to the peak amplitude of the control current, its waveform was similar to that of the control current. In all cases $(n=4)$, the antagonized, scaled currents were superimposable on control currents. This suggests that under our experimental conditions the glycinc modulatory site activation does not significantly affect the degree of desensitization of NMDA receptor-mediated synaptic currents in retinal ganglion cells.

\section{Glycine concentrations at NMDA receptors vary with $O P L$ puff stimulus strength}

The control of glycine concentrations at the retinal ganglion cell synapses has not been well studied. Several subtypes of amacrine cells in the salamander retina are glycinergic (Yang and 

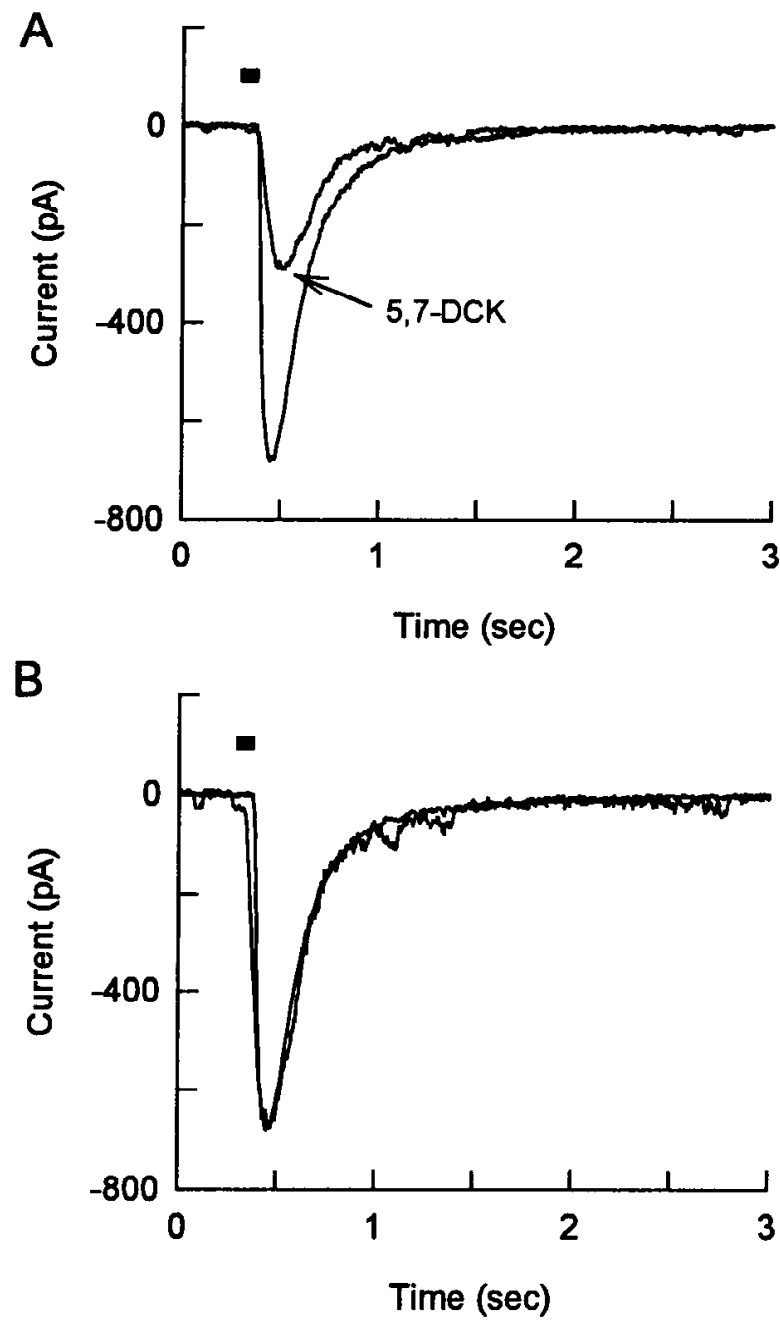

Figure 2. Glycine modulatory site antagonists do not alter ganglion cell EPSC kinetics. A. Excitatory synaptic current responses in response to excitation of bipolar cells by potassium puffs. The large amplitude response was the control response recorded when the cell was held at $30 \mathrm{mV}$. When the bath contained 5,7-DCK, the response indicated by the arrow was reduced to about $40 \%$ of the control amplitude. $R$. The response recorded in the presence of 5,7-DCK was scaled to the peak of the control response. The scaled current trace was shifted slightly so that the peaks of both traces coincided. Both the control and scaled responses decayed with the same time course. This indicates that 5,7DCK did not affect the kinetics of the ganglion cell EPSC. The bath contained $5 \mu \mathrm{M}$ CNQX and $5 \mu \mathrm{M}$ glycine, and was nominally $\mathrm{Mg}^{2+}$ free.

Yazulla, 1988; Yang et al., 1991). Presumably, these amacrine cells release glycine as a function of membrane depolarization. Since amacrine cells are also excited by puffing onto bipolar cell dendrites (Maguire et al., 1989), we wanted to determine if variations in the OPL puff strength used to stimulate EPSCs in ganglion cells also caused varying amounts of glycine release by amacrine cells, and whether this increase in glycine might reach NMDA receptors.

Ganglion cell EPSCs were measured in response to different OPL puff stimulus strengths. The puff stimulus strength was changed by varying the duration of the puff. Figure $3 A$ shows EPSCs recorded in response to a short duration OPL puff stimulus in a ganglion cell that was voltage clamped at $-30 \mathrm{mV}$. The amplitude of the short duration puff response was reduced by 5,7-DCK in a concentration-dependent manner. When the duration of the puff was increased from 27 to $300 \mathrm{msec}$ (on the same cell), the amplitude of the EPSC was increased from 132 to $300 \mathrm{pA}$ (Fig. 3B). The responses to the longer duration puffs were also reduced by 5,7-DCK in a concentration-dependent fashion. However, the concentration dependence was different for the short- versus long-duration puffs; 5,7-DCK was more potent at reducing the responses elicited by the short duration puffs than those elicited by the long duration pulfs (Fig. $3 C$ ). The concentration-response data was fit with Equation 1 to obtain the $\mathrm{IC}_{50}$ values. The $\mathrm{IC}_{50}$ of $5,7-\mathrm{DCK}$ was $0.08 \mu \mathrm{M}$ for the weak puff stimulus and $0.56 \mu \mathrm{M}$ for the strong puff stimulus. Similar shifts for $5,7-\mathrm{DCK} \mathrm{IC}_{50}$ values were seen in four additional cells. The absolute $\mathrm{IC}_{50}$ values varied due to cell-to-cell variation of the puff stimuli. They ranged from 0.08 to $1 \mu \mathrm{M}$ for the weak puff stimuli and from 0.56 to $5.4 \mu \mathrm{M}$ for the strong puff stimuli. The $\mathrm{IC}_{50}$ value for 5,7-DCK was $8.47 \pm 3.87(n$ $=5$ ) times greater for the long puffs than for the short puffs. Since 5,7-DCK is a competitive antagonist at the glycine modulatory site (McNamara et al., 1990), its $\mathrm{IC}_{50}$ values reflect the relative glycine concentrations at the NMDA receptors. These data indicate that the glycine concentrations at the NMDA receptors were higher during the responses to the long puff stimuli than during the responses to the short puff stimuli. This is consistent with glycinergic amacrine cells releasing more glycine in response to strong OPL puffs compared to weak OPL puffs.

The findings illustrated in Figure 3 are consistent with 5,7DCK acting competitively at the glycine modulatory site on the NMDA receptor complex. However, an alternative explanation that could account for these data is that 5,7-DCK could be acting competitively at the glutamate recognition site of the NMDA receptor. To distinguish between these two possibilities, we tested the interactions between 5,7-DCK and glycine as well as 5,7DCK and NMDA.

\section{5,7-Dichlorokynurenic acid acts competitively with glycine to reduce EPSCS}

To confirm that 5,7-DCK was acting competitively at the glycine site, we tested its ability to reduce puff-elicited EPSCs in ganglion cells when either 10 or $60 \mu \mathrm{M}$ glycine bathed the slice preparation (Fig. 4). The cells were clamped to $30 \mathrm{mV}$ to maximize the NMDA component of the response. The peak control responses were not changed when the bath glycine concentration was increased from 10 to $60 \mu \mathrm{M}$. However. 5.7-DCK was more effective in reducing EPSCs when the slices were bathed in $10 \mu \mathrm{M}$ glycine than in $60 \mu \mathrm{M}$ glycine. The points are the mean responses from four cells, and the bars indicate one standard deviation. The (wo curves, fit to Equation 1, were roughly parallel, and the concentration-response curve was shifted to the right with higher glycine concentration. The $\mathrm{IC}_{5,}$ value for $5.7-$ DCK was $0.78 \mu \mathrm{M}$ when the bath contained $10 \mu \mathrm{M}$ glycine and was increased to $3 \mu \mathrm{M}$ when the bath contained $60 \mu \mathrm{M}$ glycine. These data indicate that 5,7-DCK acts competitively at the glycine modulatory site to reduce the NMDA component of ganglion cell EPSCs.

\section{5,7-Dichlorokynurenic acid reduces NMDA currents noncompetitively}

If 5,7-DCK acted exclusively at the glycine modulatory site to reduce ganglion cell EPSCs, then NMDA-evoked currents should be reduced by 5,7-DCK in a noncompetitive manner. Kynurenic acid blocked NMDA responses from isolated goldfish ganglion cells in a noncompetitive manner (Yazejian and Fain, 


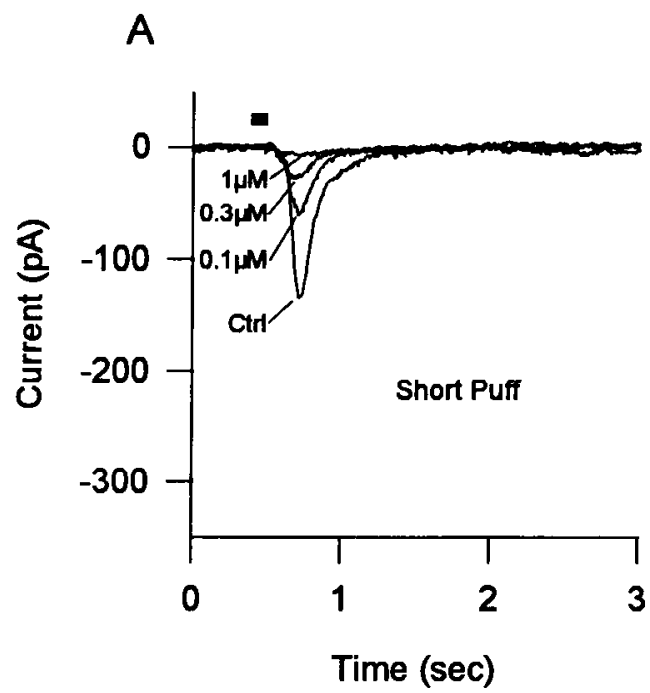

B

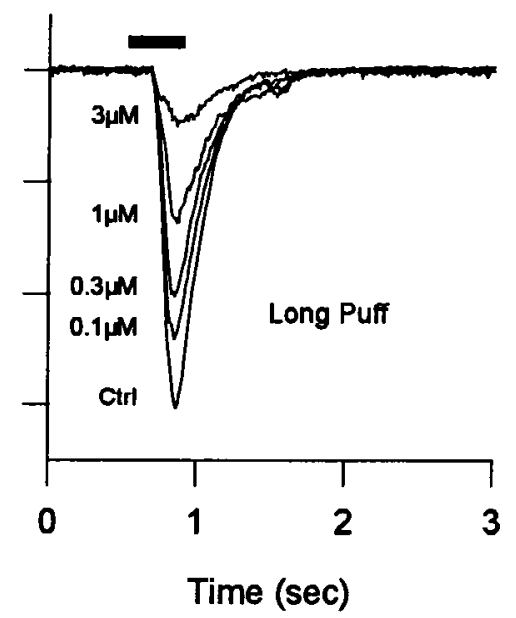

C

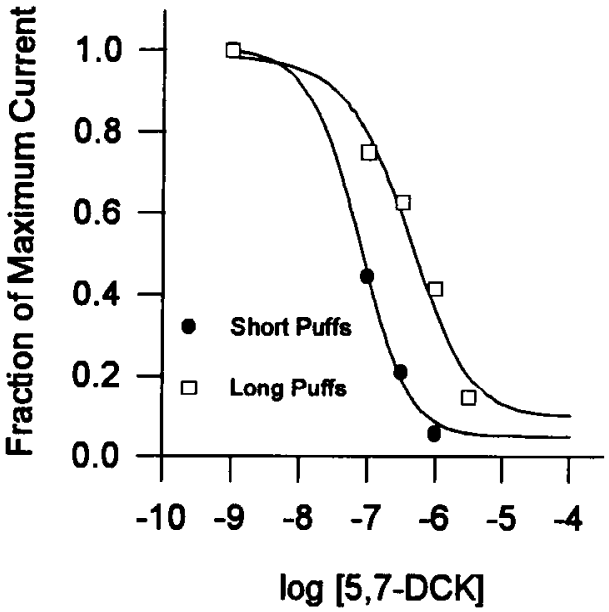

Figure 3. Synaptic glycine concentrations were increased with stimulus strength. $A$, The averaged EPSCs (three to four traces) recorded in response to a $27 \mathrm{msec}$ duration puff of potassium onto bipolar cell dendrites when the bath contained the indicated concentration of 5,7-DCK. $B$. The averaged EPSCs recorded in response to a $300 \mathrm{msec}$ puff stimulus during bath applications of the indicated concentrations of 5,7-DCK. This is the same cell as in $A . C$. The normalized peak amplitudes are plotted as function of log concentration 5,7-DCK for both the long and short duration puff stimuli. The responses to the short puffs are indicated by the solid circles and the responses to the long puffs are indicated by the open squares. The solid lines are the best fits obtained using Equation $\mathrm{I}$. The $\mathrm{IC}_{50}$ value for 5,7-DCK was $0.08 \mu \mathrm{m}$ for the short puff and $0.56 \mu \mathrm{m}$ for the long puff.

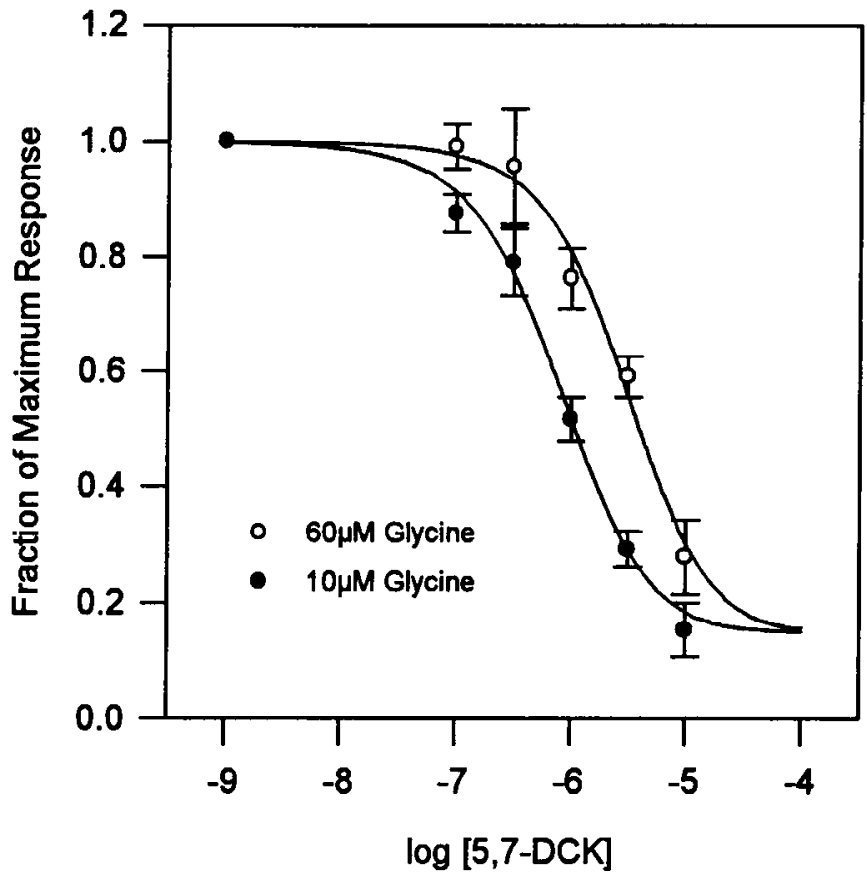

Figure 4. 5,7-DCK interacts competitively with glycine to reduce ganglion cell EPSCs. Peak amplitudes of EPSCs evoked by puffing potassium onto bipolar cell dendrites are plotted as a function of log concentration of 5,7-DCK. The points represent the mean values from four different cells when either $10 \mu \mathrm{M}$ glycine (indicated by the solid circles) or $60 \mu \mathrm{M}$ glycine (indicated by the open circles) was added to the bath. The bars indicate the sample standard deviations. The solid lines are the best fits obtained using Equation 1. The $\mathrm{IC}_{5}$ value for 5,7-DCK was $0.78 \mu \mathrm{M}$ when $10 \mu \mathrm{M}$ glycine was present and $10 \mu \mathrm{M}$ when $60 \mu \mathrm{M}$ glycine was present.
1992). To determine if 5,7-DCK was interacting with the glutamate binding site on the NMDA receptor complex, two different concentrations of NMDA were puffed onto ganglion cell dendrites after synaptic transmission was blocked in the slice by including $100 \mu \mathrm{M} \mathrm{CdCl}$ in the bath. The duration of the puff was adjusted to evoke either a small or a large amplitude response. The pipette concentration of NMDA was $1 \mathrm{~mm}$. Figure $5 A$ shows averaged control responses to short and long duration puffs, reflecting low and high concentrations of NMDA, respectively. When the normalized, peak amplitudes of the responses for both stimuli are plotted as a function of 5,7-DCK concentration in Figure $5 B$, the concentration-response curves and the $\mathrm{IC}_{50}$ values were identical. Similar results were obtained in four additional cells. Thus 5,7-DCK was equally effective in reducing the large and small amplitude responses to NMDA. This noncompetitive interaction between 5,7-DCK and NMDA indicates that $5,7-\mathrm{DCK}$ was not acting at the glutamate binding site, but acted competitively at the glycine modulatory site to reduce the NMDA-evoked currents.

\section{Light-evoked EPSCs were reduced by 5,7-DCK}

To determine how synaptic glycine concentrations may be regulated under more physiological conditions, we also used light to elicit ganglion cell EPSCs. Full-field light stimuli were used to elicit EPSCs in ON-OFF ganglion cells. The EPSCs were pharmacologically isolated by including $150 \mu \mathrm{M}$ picrotoxin and $2 \mu \mathrm{M}$ strychnine in the bathing medium. Tetrodotoxin and cesium were used to block voltage-gated currents as described above. The ganglion cells were voltage clamped to $-30 \mathrm{mV}$ to relieve the magnesium blockade of the NMDA channels and to maximize the NMDA component of the ganglion cell EPSCs. 


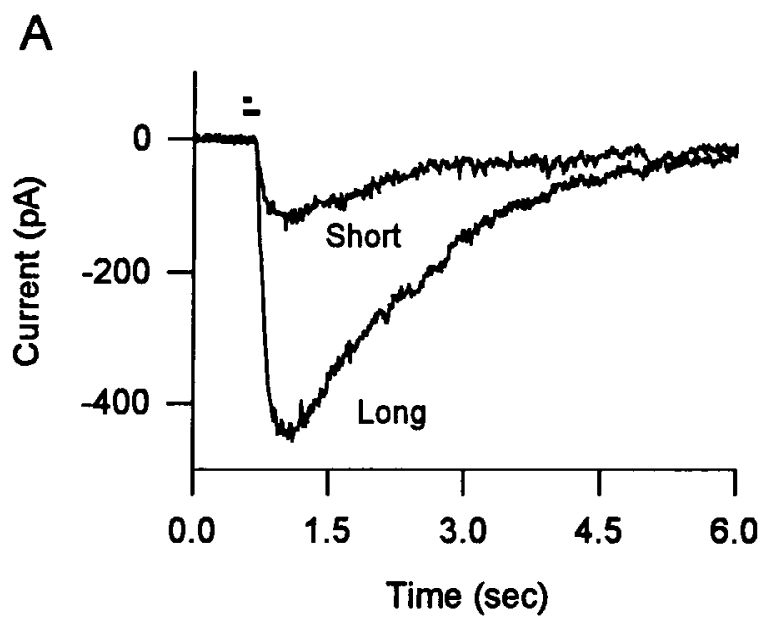

B

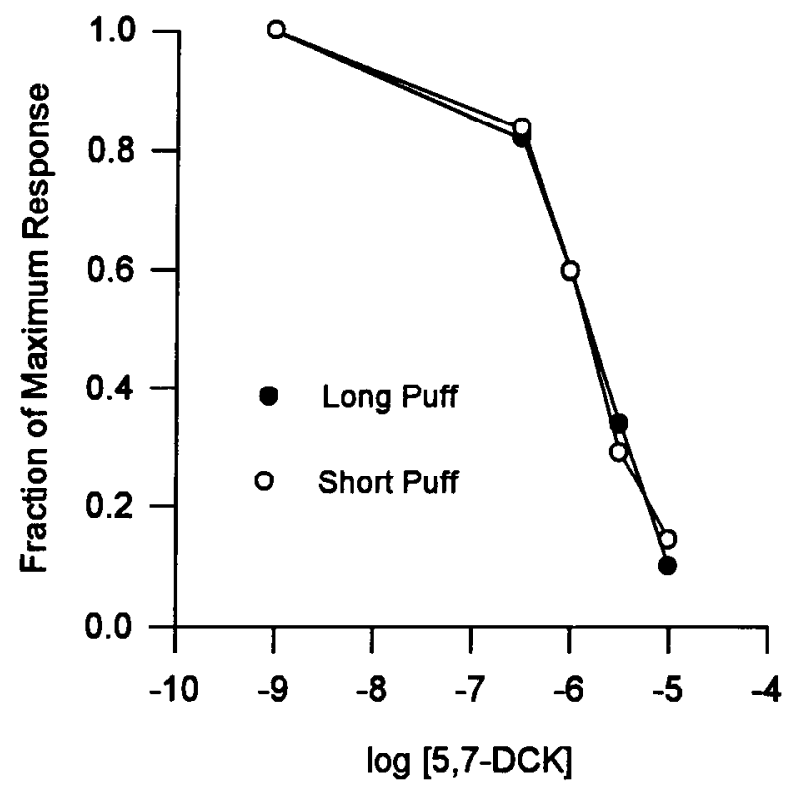

Figure 5. 5,7-DCK noncompetitively antagonized NMDA currents. NMDA was puffed onto ganglion cell dendrites after synaptic transmission was blocked with $100 \mu \mathrm{M} \mathrm{CdCl}$. The bathing solution contained $5 \mu \mathrm{M}$ glycine and no added $\mathrm{Mg}^{2+}$. The cell was voltage clamped to $-75 \mathrm{mV}$. A, Averaged current responses (four traces) to two concentrations of NMDA. The concentration of NMDA was altered by varying the duration of the puff stimulus. The concentration of NMDA in the puffer was $1 \mathrm{~mm}$. $B$, The peak amplitudes of the responses to short and long duration puffs are plotted as a function of antagonist concentration. Responses to the short puffs are indicated by the open circles and responses to the long puffs are indicated by the solid circles. 5,7-DCK reduced the responses to both the short and long puffs of NMDA in a concentration-dependent manner. The $\mathrm{IC}_{50}$ values for 5,7-DCK were identical for both concentrations of NMDA.

Figure $6 A$ shows a family of light-elicited EPSCs recorded from an ON-OFF ganglion cell. Both the $O N$ and the OFF EPSCs were reduced by $5,7-\mathrm{DCK}$ in a concentration-dependent manner. The ON and OFF responses still present at the highest concentrations of 5,7-DCK were probably mediated by nonNMDA receptors (see above). The peak amplitudes of both the $\mathrm{ON}$ and OFF EPSCs are plotted as a function of log concentration of 5,7-DCK in Figure $6 B$. The concentration-response data was fit with Equation 1 to obtain the $\mathrm{IC}_{50}$ values. The $\mathrm{IC}_{50}$ values for the effect of 5,7-DCK on the ON and OFF EPSCs were 0.67 $\mu \mathrm{M}$ and $0.09 \mu \mathrm{M}$, respectively. Since 5,7-DCK acts competitively at the glycine modulatory site, the different $\mathrm{IC}_{51}$ values at $\mathrm{ON}$ and OFF indicate that the glycine concentrations at the NMDA receptors mediating $O N$ and OFF ganglion cell EPSCs were different. Alternatively, different subtypes of NMDA receptors with different glycine sensitivities may mediate $\mathrm{ON}$ and $\mathrm{OFF}$ EPSCs.

In order to determine if the glycine concentrations at NMDA receptors on ganglion cells could he physiologically modulated, we estimated the synaptic glycine concentrations at different light stimulus intensities. Figure $6 C$ shows the same cell as in Figure $6 A$, but in this case the cell was stimulated with a light stimulus that was 10,000 times brighter. As with the dimmer light stimuli, 5,7-DCK reduced both the ON and OFF EPSCs in a concentration-dependent manner.

The apparent variation in synaptic glycine levels with light stimulus intensity can be seen by comparing Figure $6, B$ and $D$. For both the ON and OFF EPSCs, the $\mathrm{IC}_{50}$ values for 5,7-DCK were shifted to the higher values with increased light intensity indicating increased glycine concentrations at the NMDA receptors. With increased light stimulus intensity the $\mathrm{IC}_{50}$ values for the ON EPSCs, were shifted from 0.67 to $1.5 \mu \mathrm{M}$ and for OFF EPSCs the $\mathrm{IC}_{50}$ values were shifted from 0.09 to $1.82 \mu \mathrm{M}$. For the dim light stimuli, the mean $\mathrm{IC}_{5,}$ values for $5,7-\mathrm{DCK}$ in six cells ON-OFF ganglion cells were $0.8 \pm 0.36 \mu \mathrm{M}$ for the ON EPSCs and $0.12 \pm 0.049 \mu \mathrm{M}$ for the OFF EPSCs. At this light intensity, the OFF EPSCs were thus approximately seven times more sensitive to 5,7-DCK than the ON EPSCs. At the brighter stimulus intensity, the mean $\mathrm{IC}_{50}$ values for $5.7-\mathrm{DCK}$ were 1.23 $\pm 0.4 \mu \mathrm{m}$ for the ON EPSCs and $1.3 \pm 0.66 \mu \mathrm{M}$ for the OFF EPSCs. In contrast to dim light stimuli, with brighter light stimuli, the ON and OFF EPSCs were thus about equally sensitive to 5,7-DCK. For the OFF EPSCs, the brighter light intensity caused a significant increase of the mean $\mathrm{IC}_{5,}$ value for 5,7-DCK $(p<0.01$, Student's $t$ test). However, there was no significant effect of increased light intensity on the mean $\mathrm{IC}_{50}$ value for the ON EPSCs $(p>0.05$, Student's $t$ test $)$.

\section{The effects of glycine and D-serine on light-evoked EPSCs}

Are the synaptic glycine concentrations saturating during light elicited EPSCs? Initially, we attempted to study how glycine modulated the NMDA receptor component of $\mathrm{K}^{+}$puff-elicited EPSCs by changing the concentration of glycine in the bath. When the bath concentration of glycine was varied from 0 to $10 \mu \mathrm{M}$, the amplitudes of the EPSCs were not altered. This suggests that with our experimental conditions the retinal slice endogenous glycine concentrations at the NMDA receptors were either saturated or that the glycine levels were buffered by uptake mechanisms in the retina. To test whether uptake mechanisms were preventing glycine from exerting an effect, we tested the ability of high bath concentrations of glycine or the nontransportable glycine analog D-serine to potentiate EPSCs evoked by dim light stimuli. The ganglion cells were voltage clamped to $-30 \mathrm{mV}$. Inhibitory synaptic inputs and voltagegated currents were blocked as described above. The results were obtained from $12 \mathrm{ON}-\mathrm{OFF}$ and $3 \mathrm{ON}$ ganglion cells. For comparison, the effects upon ON-EPSCs are described below. Both OFF EPSCs and ON EPSCs responded to D-serine or glycine in a similar manner.

Surprisingly, for dim stimuli $(-6.4$ to $-8.0 \mathrm{log}$ attenuation). bath application of D-serine caused a suppression of the light- 
A

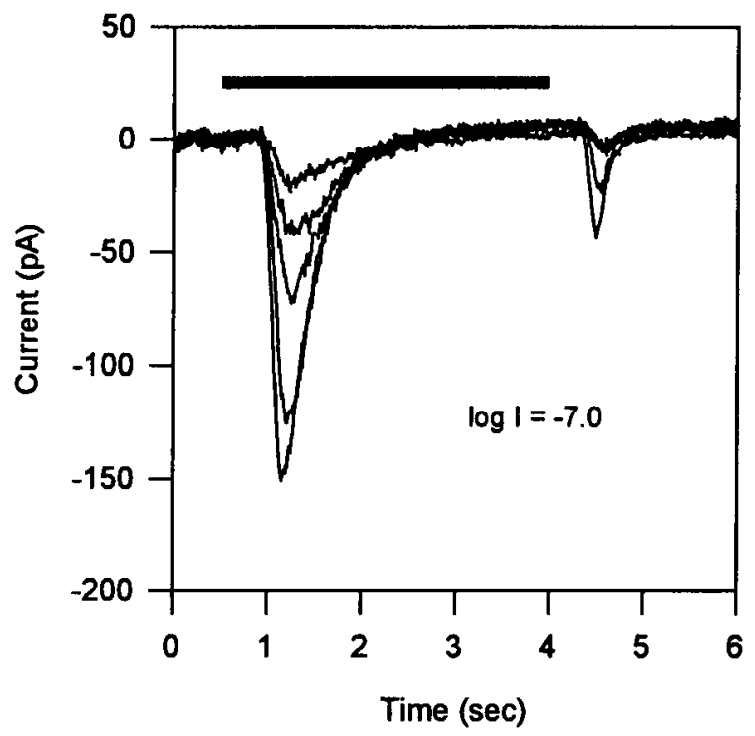

C

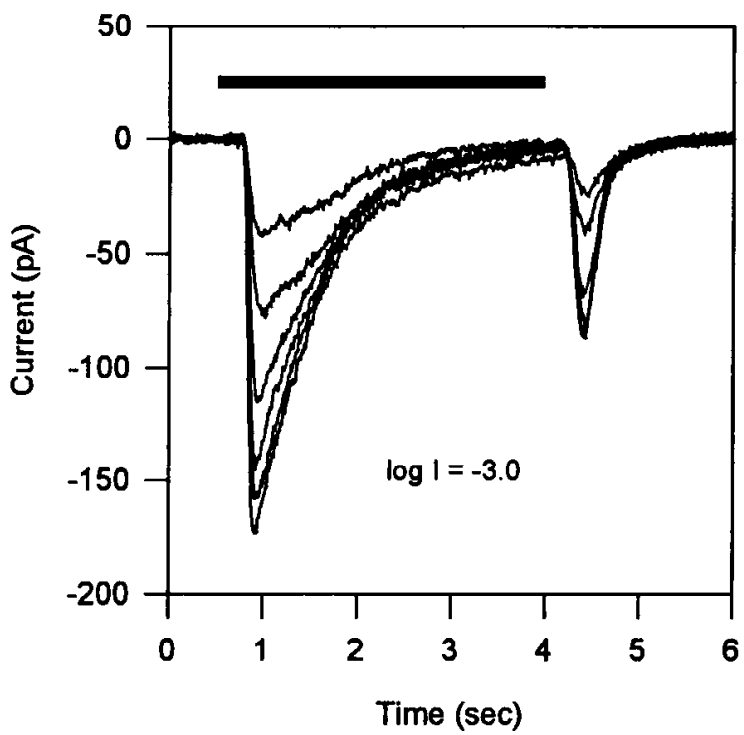

B

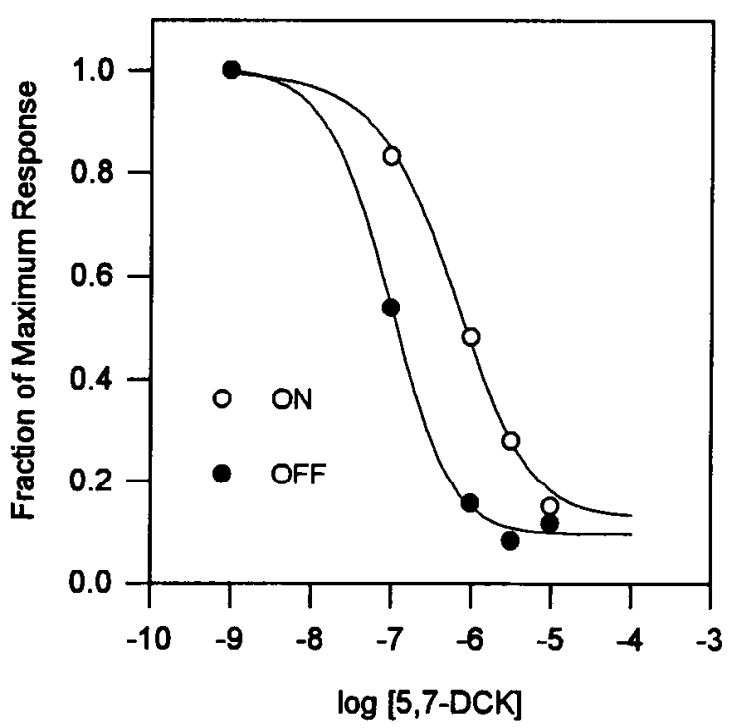

D

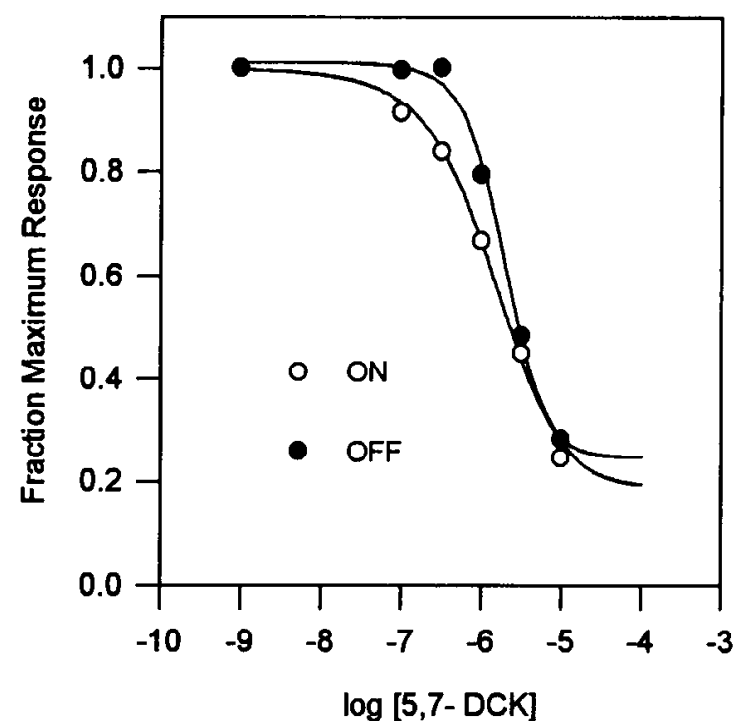

Figure 6. 5,7-DCK reduced both the ON and the OFF light responses in an ON-OFF ganglion cell. $A$, Light-evoked EPSCs in an ON-OFF ganglion cell in the presence of different concentrations of 5,7-DCK. Each current trace is the average of three to five responses to a light stimulus attenuated by seven log units. The largest response was the control, and the increasingly smaller responses were recorded in the presence of 0.1 , 1.0. 3.0, and $10.0 \mu \mathrm{M} 5,7-\mathrm{DCK}$, respectively. B. The peak amplitudes of both the ON (open circles) and OFF (solid circles) EPSCs are plotted as a function of log concentration of 5,7-DCK. The OFF EPSC was more sensitive to antagonism by 5,7-DCK than the ON EPSC. The 5.7-DCK IC 5 . values for blockade of the EPSCs were $0.09 \mu \mathrm{M}$ for the OFF response and $0.67 \mu \mathrm{M}$ for the ON response. $C$, Same cell as in $A$. Details as in $A$, except that the intensity of the light stimulus was brighter, attenuated by only three $\log$ units. $D$. The peak amplitudes of both the ON (open (ircles) and UFF (solid circles) EPSC's are plotted as a function of $\log$ concentration 5,7-DCK. The ON EPSC was slightly more sensitive to antagonism by 5,7-DCK than the OFF EPSC. The 5,7-DCK IC ${ }_{50}$ values for blockade of the EPSCs were $1.82 \mu \mathrm{M}$ for the OFF response and $1.5 \mu \mathrm{M}$ for the ON response. The solid lines in both $B$ and $D$ are the best fits obtained using Equation 1 .

evoked EPSCs in all cells tested. The suppression was concentration dependent, $100 \mu \mathrm{M}$ D-serine reduced the EPSC amplitudes to $30 \pm 21 \%$ of controls $(n=7)$, while $1 \mathrm{~mm}$ D-serine reduced the responses to $7 \pm 5 \%$ of controls $(n=6)$. Figure $7 B$ shows that D-serine (1 $\mathrm{mm}$ ) reversibly suppressed both the ON and OFF EPSCs recorded from an ON-OFF ganglion cell. High concentrations of bath applied glycine also suppressed light-evoked EPSCs in a reversible manner as shown in Figure
$7 A$. Light-evoked responses were reduced to $1 \pm 2 \%$ of control amplitudes by $1 \mathrm{mM}$ glycine $(n=4)$.

We also determined if D-serine $(100-1000 \mu \mathrm{M})$ could modulate the NMDA receptor component of the potassium puff-elicited EPSCs. The results were variable. D-Serine potentiated the potassium puff-elicited EPSCs (124 $\pm 6 \%$ of control) in three cells, had no effect on the EPSCs in five cells, and suppressed $(60 \pm 26 \%$ of control) the EPSCs in nine cells. 
A

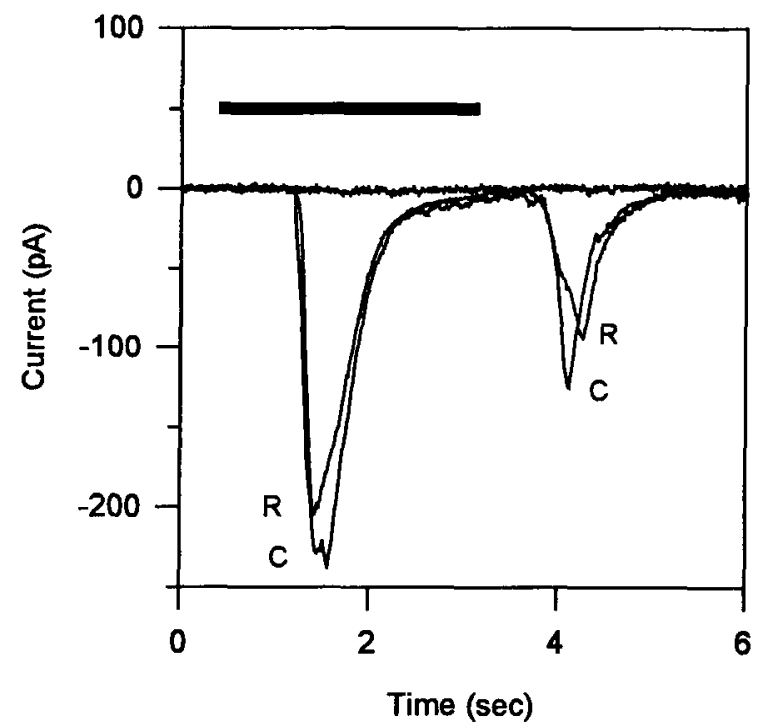

B

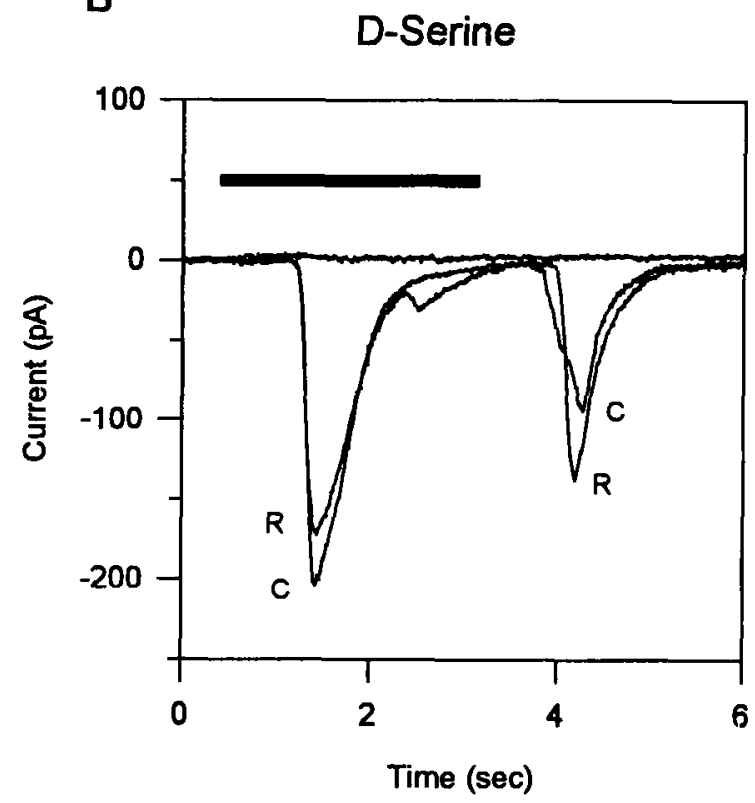

Figure 7. Glycine and D-serine reversihly suppressed light-evoked FPSCs. A, Light-elicited EPSCs from an ON-OFF ganglion cell recorded in the absence and presence of $1 \mathrm{~mm}$ glycine in the bath. The control response is labeled $C$. The flat trace was recorded in the presence of glycine. Glycine suppressed both the ON and OFF light-evoked EPSCs. The current trace labeled $R$ indicates that both the ON and OFF responses recovered upon washout of the glycine. $B$. The same cell and experimental protocol as in $A$. The flat trace was recorded in the presence of 1 mm bath applied D-serine after recovery from the glycine application. Recovery of both the ON and OFF light responses occurred upon washout of the D-serine. Each current trace is the average of three to five responses. To ensure that inhibitory glycine receptors were not activated, the bath strychnine concentration was increased from 2 to $20 \mu \mathrm{M}$. The light stimulus was attenuated by 8.0 log units. The cell was voltage clamped to $-30 \mathrm{mV}$.

\section{Discussion}

The NMDA-mediated component of the ganglion cell EPSCs was reduced by 5,7-DCK in a concentration-dependent manner. The EPSC suppression by 5,7-DCK was due to its competitive interaction with the glycine binding site on the NMDA receptor. Direct NMDA-evoked currents were reduced by 5,7-DCK in a noncompetitive manner. Taken together, these results indicate that 5,7-DCK reduces ganglion cell EPSCs by a selective action at the glycine modulatory site on the NMDA receptor complex.

Retinal ganglion cells have been shown to receive glycinergic inputs as well as glutamatergic synaptic inputs. This arrangement suggests that glycine concentrations at the NMDA receptors may vary with activity of the glycinergic amacrine cells. Using the competitive antagonist 5,7-DCK, we have been able to determine the relative glycine concentrations at the NMDA receptors on ganglion cells. When puffs of potassium onto bipolar cell dendrites were used to elicit EPSCs in ganglion cells, we found that the $\mathrm{IC}_{50}$ values for $5,7-\mathrm{DCK}$ increased as a function of puff stimulus strength. These findings suggest that synaptic glycine concentrations were higher in response to the stronger puff stimuli, most likely due to enhanced excitation of glycinergic amacrine cells by the stronger puff stimuli (Maguire et. al., 1990). Glycine concentrations at NMDA receptors also increased as a function of light stimulus intensity, most likely due to enhanced excitation of glycinergic amacrine cells.

\section{Are glycine levels saturating at the NMDA receptor?}

The modulatory role of glycine at NMDA receptors in the CNS is controversial. In the neocortex (Thomson et al., 1989; Daw et al., 1993) and in the thalamus (Salt, 1989), glycine agonists may potentiate NMDA-mediated responses. Also, in vivo biochemical studies have shown that glycine agonists enhanced
NMDA receptor-mediated increases in cerebellar cGMP concentrations (Danysz et al., 1989; Wood et al., 1991). Results from these biochemical and physiological studies suggest that endogenous glycine levels at NMDA receptors were not saturating and that exogenous glycine could modulate the activity of NMDA receptors. Using cortical tissue, others (Fletcher et al., 1988; Kemp et al., 1988) have found that added glycine did not enhance NMDA-evoked responses and concluded that endogenous glycine levels were saturating. However, as suggested by Kemp and Leeson (1993), the endogenous glycine levels could have been subsaturating, but the application of NMDA caused the release of glycine to saturating levels.

We attempted to potentiate the amplitude of ganglion cell light responses with high concentrations of bath-applied glycine and the glycine agonist, D-serine. Surprisingly, high concentrations of glycine and D-serine suppressed ganglion cell light-elicited EPSCs. The mechanism of this suppression in unclear. The glycine agonists did not directly inhibit ganglion cells because 20 $\mu \mathrm{M}$ strychnine was present in the bath and outward currents in response to these agonists were never observed when the cells were held at $-30 \mathrm{mV}$. The fact that glycine and $\mathrm{D}$-serine almost completely blocked the EPSCs indicates that both the NMDA and non-NMDA components of the response were reduced. This suggests that these substances may exert their suppressive actions at a site presynaptic to the ganglion cell. D-Serine was not as effective in suppressing puff-elicited EPSCs as the lightevoked EPSCs. Since the $\mathrm{K}^{+}$puffs onto bipolar dendrites probably bypassed synaptic transmission in the outer retina. the reduced effectiveness of D-serine suggests that the site of the suppression may be, in part, at the outer retina. NMDA receptors are not found in the outer retina of salamander (Slaughter and Miller, 1983a,b). However, the glycine agonists may activate 
NMDA receptors on an amacrine or an interplexiform cell that releases a modulator substance that, in turn, suppresses synaptic transmission in the outer retina. If we can dissociate the suppressive effects of the glycine agonists from their modulatory actions at the NMDA receptor, then we will be able to determine whether light-evoked EPSCs can be potentiated by applied glycine agonists.

In just under half of the cells tested, D-serine did not suppress the puff-elicited EPSCs. EPSCs were potentiated by D-serine in three of these cells, suggesting that synaptic glycine concentrations were not saturated. However, synaptic glycine concentrations were probably saturated for the five cells where no enhancement of the EPSC's was observed. Alternatively, the enhancing actions of $\mathrm{D}$-serine could have been offset by its suppressive effects in these five cells.

\section{Site of action of $5,7-D C K$}

Our results can be explained by 5,7-DCK acting at the ganglion cells to antagonize the actions of glycine at the NMDA receptor. Since some subtypes of amacrine cells also possess NMDA receptors (Dixon and Copenhagen, 1992), 5,7-DCK may also act, in part, at amacrine cells. Excitatory synaptic inputs to glycinergic amacrine cells may be reduced by 5,7-DCK, resulting in a reduced release of glycine. The reduced levels of glycine release would contribute to the suppression of ganglion cell EPSCs. This scenario assumes that (1) NMDA receptors play a major role in the depolarization of glycinergic amacrine cells, and (2) that glycinergic amacrine cells do, indeed, have NMDA receptors that are modulated by glycine. If these assumptions are correct, it is unclear as to what extent reducing the NMDA component would reduce glycine release, since those subtypes of amacrine cells that possess NMDA receptors also utilize nonNMDA receptors. Non-NMDA receptors can probably still sustain glycine release, especially at membrane potentials where magnesium blockade occurs. Furthermore, our experiments were performed in the presence of $\mathrm{Mg}^{2+}$, and only the ganglion cell from which the recordings were obtained was voltage clamped to $-30 \mathrm{mV}$. This would have biased the $5,7-\mathrm{DCK}$ effects in favor of the ganglion cell and would have minimized its effects at the amacrine cells. Nevertheless, we cannot rule out the possibility that a portion of the actions of 5,7-DCK also occur at glycinergic amacrine cells.

\section{Coagonist and modulatory roles of glycine}

Our results suggest that glycine acts as a coagonist at the ganglion cell NMDA receptors. When the NMDA component was isolated by including $5 \mu \mathrm{M}$ CNQX in the bath, the OPL potassium puff elicited EPSC was completely blocked by $10 \mu \mathrm{M} 5,7$ DCK (data not shown). This indicates that glycine is essential for the gating of NMDA receptor-mediated synaptic currents in ganglion cells.

Increasing the light stimulus intensity significantly enhanced the mean $\mathrm{IC}_{50}$ value of 5,7-DCK for the OFF, but not the ON, EPSCs. The $\mathrm{IC}_{50}$ value for the ON EPSCs may not have changed because the amplitudes of the ON EPSCs were similar for both the dim and bright stimuli. When dimmer stimuli were used in attempts to obtain a smaller amplitude ON EPSC, we could no longer record an OFF response. The lack of change in ON EPSC amplitudes probably reflects comparable levels of glutamate and/ or glycine release from bipolar and amacrine cells, respectively, for the two stimulus conditions. The similarities in the mean $I_{50}$ values for 5,7 -DCK indicate that synaptic glycine levels were comparable for dim and bright stimuli, and suggests that the rate of amacrine cell glycine release was similar for the two stimulus conditions at the synapses mediating ON, but not OFF EPSCs.

We do not know if the synaptic glycine concentrations were saturating in our light stimulus experiments. The $K_{d}$ values for glycine and 5,7-DCK at ganglion cell NMDA receptors are not known. However, if we use the $K_{d l}$ values for glycine $(0.67 \mu \mathrm{M})$ reported by Kleckner and Dingledine (1988) and the $K_{d}$ value for 5,7-DCK $(0.065 \mu \mathrm{M})$ reported by McNamara et al. (1990), then we can estimate the synaptic glycine concentrations from our $\mathrm{IC}_{50}$ values for 5,7-DCK. Using the rearranged Cheng-Prusoff equation (Cheng and Prusoff. 1973),

$$
\mathrm{IC}_{5 !}=K_{\mathrm{ICCK}}\left(1+\frac{X}{K_{\text {(II.YY }}}\right),
$$

we calculated the estimated glycine concentrations from our 5,7DCK IC ${ }_{5 i}$ values, where $K_{\mathrm{DCK}}$ is the $K_{t}$ for $5,7-\mathrm{DCK}, K_{\mathrm{Ci} . Y}$ is the $K_{d}$ for glycine, and $X$ is the synaptic glycine concentration. For six ON-OFF ganglion cells, the mcan estimated glycine concentrations increased with light stimulus intensity from 0.57 to 12.7 $\mu \mathrm{M}$ at the OFF synapse. For the ON synapse, the mean estimated glycine concentration increased from 7.6 to $12.0 \mu \mathrm{M}$ with increasing light intensity. If these $K_{d}$ values taken from frog oocyte experiments are similar to those for salamander ganglion cells, then glycine concentrations at the OFF synapse were not saturated at low light intensities. In contrast, the glycine concentrations at the ON synapse were probably saturated even at low light intensities. We are currently attempting to measure the $K_{d}$ values for glycine and 5,7-DCK using isolated salamander ganglion cells in order to more accurately determine synaptic glycine concentrations in the slice.

Inhibitory synaptic inputs were blocked by strychnine and picrotoxin in our experiments. It is possible that under these conditions of disinhibition that there was an increased release of glycine from amacrine cells. If this were the casc, then our calculations may overestimate typical synaptic glycine concentrations. This would imply that in normal retinal function, synaptic glycine concentrations may be even further below saturation and, hence, could modulate NMDA receptor activity over a larger range.

\section{References}

Barnes S, Werblin F (1986) Gated currents generate single spike activity in amacrine cells of the tiger salamander retina. Proc Natl Acad Sci USA 83:1509-1512.

Barnes S, Werblin F (1987) Direct excitatory and lateral inhibitory synaptic inputs to amacrine cells in the tiger salamander retina. Brain Res 406:233-237.

Belgum JH, Dvorak DR, McReynolds JS (1984) Strychnine blocks transient but not sustained inhibition in mudpuppy retinal ganglion cells. J Physiol (Lond) 354:273-286.

Benveniste M, Mayer M (1993) Multiple effects of spermine on NMDA receptor responses of rat cultured hippocampal neurones. $\mathbf{J}$ Physiol (Lond) 464:131-163.

Cheng Y-C, Prusoff, WH (1973) Relationship between the inhibition constant $\left(\mathrm{K}_{1}\right)$ and the concentration of inhibitor which causes 50 percent inhibition $\left(I_{50}\right)$ of an enzymatic reaction. Biochem Pharmacol 22:3099-3108.

Danysz W, Wroblewski JT, Brooker G, Costa E (1989) Modulation of glutamate receptors by phencyclidine and glycine in the rat cerebellum: cGMP increase in vivo. Brain Res 479:270-276.

Daw NW, Czepita D, Reid S (1993) Is the glycine site at the NMDA receptor saturated in the cat visual cortex? Invest Ophthalmol Vis Sci 34:1174.

Diamond JS, Copenhagen DR (1993) The contribution of NMDA and 
non-NMDA receptors to the light-evoked input-output characteristics of retinal ganglion cells. Neuron 11:725-738.

Dixon DB, Copenhagen DR (1992) Two types of glutamate receptors differentially excite amacrine cells in the tiger salamander retina. $\mathbf{J}$ Physiol (Lond) 449:589-606.

Famiglietti EV, Kolb H (1976) Structural basis for ON- and OFF-center responses in retinal ganglion cells. Science 194:193-195.

Famiglietti EV, Kaneko A, Tachibana M (1977) Neuronal architecture of $\mathrm{ON}$ and $\mathrm{OFF}$ pathways to ganglion cells in carp retina. Science 198:1267-1269.

Fletcher EJ, Lodge D (1988) Glycine reverses antagonism of $N$-methylD-aspartate (NMDA) by 1-hydroxy-3-aminopyrrolidone-2 (HA-966) but not by D-2-amino-5-phosphonovalerate (D-AP5) on rat cortical slices. Eur J Pharmacol 151:161-162.

Gottesman J, Miller RF (1992) Pharmacological properties of $N$-methyl-D-aspartate receptors on ganglion cells of an amphibian retina. J Neurophysiol 68:596-604.

Hamill OP, Marty A, Neher E, Sakmann B, Sigworth FJ (1981) Improved patch clamp techniques for high resolution current recording from cells and cell-free patches. Pfluegers Arch 391:85-100.

Hensley SH, Yang X-L, Wu SM (1993) Relative contribution of rod and cone inputs to bipolar cells and ganglion cells in the tiger salamander retina. J Neurophysiol 69:2086-2098.

Huettner JE (1989) Indolc-2-carboxylic acid: a competitive antagonist of potentiation by glycine at the NMDA receptor. Science 243:16111613.

Johnson JW, Ascher P (1987) Glycine potentiates the NMDA response in cultured mouse brain neurons. Nature 325:529-533.

Kemp JA, Leeson PD (1993) The glycine site of the NMDA receptorfive years on. Trends Pharmacol Sci 14:20-25.

Kemp JA, Foster AC, Leeson PD, Priestley T, Tridgett R, Iversen LL, Woodruff GN (1988) 7-Chlorokynurenic acid is a selective antagonist at the glycine modulatory site of the $N$-methyl-D-aspartate receptor complex. Proc Natl Acad Sci USA 85:6547-6550.

Kleckner NW, Dingledine R (1988) Requirement for glycine in activation of NMDA-receptors expressed in Xenopus oocytes. Science 241:835-837.

Kleckner NW, Dingledine R (1989) Selectivity of quinoxalines and kynurenines as antagonists of the glycine site on NMDA receptors in Xenopus oocytes. Mol Pharmacol 36:430-436.

Lester RA, Quarum ML, Parker JD, Werber E, Jahr C'E (1989) Interaction of 6-cyano-7-nitroquinoxaline-2,3-dione with the NMDA receptor-associated glycine binding site. Mol Pharmacol 35:656-570.

Lester RA, Tong G, Jahr CE (1993) Interactions between the glycine and glutamate binding sites of the NMDA receptor. J Neurosci 13: $1088-1096$.

Lukasiewicz PD, McReynolds IS (1985) Synaptic transmission at $\mathrm{N}$-methyl-D-aspartate receptors in the proximal retina of the mudpuppy. J Physiol (Lond) 367:99-115.

Lukasiewicz P, Werblin F (1988) A slowly inactivating potassium current truncates spike activity in ganglion cells of the tiger salamander retina. J Neurosci 8:4470-4481.

Lukasiewicz PD, Werblin FS (1990) The spatial distribution of excitatory and inhibitory inputs to ganglion cell dendrites in the tiger salamander retina. J Neurosci 10:210-221.

Lukasiewicz PD, Werblin FS (1994) A novel GABA receptor modulates synaptic transmission from bipolar to ganglion and amacrine cells in the tiger salamander retina. J Neurosci 14:1213-1223.

Maguire G, Lukasiewicz P, Werblin F (1989) Amacrine cell interactions underlying the response to change in the tiger salamander retina. J Neurosci 9:726-735.

Mayer ML, Westbrook GL, Guthrie PB (1984) Voltage-dependent block by $\mathrm{Mg}^{2+}$ of NMDA responses in spinal cord neurones. Nature 309:261-263.

Mayer ML, Vyklicky L, Clements J (1989) regulation of NMDA receptor desensitization in mouse hippocampal neurons by glycine. $\mathrm{Na}$ ture 338:425-427.

McGurk JF, Bennett MVL, Zukin RS (1990) Polyamines potentiate responses of $N$--methyl-D-aspartate receptors expressed in Xenopus oocytes. Proc Natl Acad Sci USA 87:9971-9974.
McNamara D, Smith ECR, Calligaro DO, O'Malley PJ, McQuaid LA, Dingledine R (1990) 5,7-Dichlorokynurenic acid, a potent and selective competitive antagonist of the glycine site on NMDA receptors. Neurosci Lett 120:17-20.

Miller RF, Frumkes TE, Slaughter M, Dacheux RF (1981) Physiological and pharmacological basis of GABA and glycine action on neurons of mudpuppy retina. II. Amacrine and ganglion cells. J Neurophysiol 45:764-782.

Mittman S, Taylor WR, Copenhagen DR (1990) Concomitant activation of two types of glutamate receptor mediates excitation of salamander retinal ganglion cells. J Physiol (Lond) 428:175-197.

Nawy S, Jahr CE (1990) Suppression by glutamate of cGMP-activated conductance in retinal bipolar cells. Nature 346:269-271.

Nelson R, Famiglietti EV Jr, Kolb H (1978) Intracellular staining reveals different levels of stratification for ON- and OFF-center ganglion cells in cat retina. J Neurophysiol 41:472-483.

Nowak L, Bregestovski P, Ascher P, Herbet A, Prochiantz A (1984) Magnesium gates glutamate-activated channels in mouse central neurones. Nature 307:462-465.

Peters S, Koh J, Choi DW (1987) Zinc selectively blocks $N$-methyl-Daspartate on cortical neurons. Science 236-589-593

Ransom RW, Deschenes NL (1990) Polyamines regulate glycine interaction with $N$-methyl-D-aspartate receptor. Synapse 5:294-298.

Ransom RW, Strec NL (1988) Cooperative modulation of [ $\left.{ }^{3} \mathrm{H}\right] \mathrm{MK} 801$ binding to $N$-methyl-D-aspartate receptor-ion channel complex by L-glutamate, glycine and polyamines. J Neurochem 51:830-836.

Rock DM, MacDonald RL (1992a) The polyamine spemine has multiple actions on $\mathrm{N}$-methyl-D-aspartate receptor single-channel currents in cultured cortical neurons. Mol Pharmacol 41:83-88.

Rock DM, MacDonald RL (1992b) Spermine and related polyamines produce a voltage-dependent reduction of $N$-methyl-D-aspartate receptor single-channel conductance. Mol Pharmacol 42:157-164.

Sacaan AI, Johnson KM (1989) Spermine enhances binding to the glycine site associated with the $N$-methyl-D-aspartate receptor complex. Mol Pharmacol 36:836-839.

Salt TE (1989) Modulation of NMDA receptor-mediated responses by glycine and D-serine in the rat thalamus in vivo. Brain Res 481:403406.

Slaughter MM, Miller RF (1983a) An excitatory amino acid antagonist blocks cone input to sign-conserving second-order retinal neurons. Science 219:1230-1232.

Slaughter MM, Miller RF (1983b) The role of excitatory amino acid transmitters in the mudpuppy retina: an analysis with kainic acid and $N$-methylaspartate. J Neurosci 3:1701-1711.

Stewart WW (1978) Functional connections between cells as revealed by a highly fluorescent naphthalimide tracer. Cell 14:741-759.

Thomson AM, Walker VE, Flynn DM (1989) Glycine enhances NMDA-receptor mediated synaptic potentials in neocortical slices. Nature 338:422-424.

Werblin FS (1978) Transmission along and between rods in the tiger salamander retina. J Physiol (Lond) 280:449-470.

Westbrook GL. Mayer ML (1987) Micromolar concentrations of $\mathrm{Zn}^{2+}$ antagonize NMDA and GABA responses of hippocampal neurons. Nature 328:640-643.

Williams K, Dawson VL, Romano C, Dichter MA, Molinoff PB (1990) Characterization of polyamines having agonist, antagonist, and inverse agonist effects at the polyamine recognition site of the NMDA reccptor. Ncuron 5:199-208.

Wood PL, Rao TS (1991) A review of in vivo modulation of cerebellar cGMP levels by excitatory amino acid receptors: role of NMDA, quisqualate and kainate subtypes. Prog Neuropsychopharmacol Biol Psychiatry 15:229-235.

Yang C-Y, Yazulla S (1988) Light microscopic localization of putative glycinergic neurons on the larval tiger salamander retina by immunocytochemical and autoradiographical methods. J Comp Neurol 272: 343-357.

Yang C-Y, Lukasiewicz P, Maguire G, Werblin F, Yazulla S (1991) Amacrine cells in the tiger salamander retina: morphology, physiology, and neurotransmitter identification. J Comp Neurol 311:1-14.

Yazejian B, Fain GL (1992) Excitatory amino acid receptors on isolated retinal ganglion cells from goldfish. J Neurophysiol 67:94-107. 